\title{
Holokaust jako ludobójstwo wyjątkowe
}

\author{
The Holocaust as an Unique Genocide
}

Aвstract: The article is dedicated to an analysis of the Holocaust uniqueness against the backdrop of other genocides. Most of all, the text follows the clues from Berel Lang, who interprets the Nazi Crime as a perfect genocide, that is, such a genocide that implemented its ideological assumptions fully for the first time in human history. What transpired then was in fact a comprehensive synthesis of "idea" and "actions." Therefore, the relation between the Holocaust and other genocides turns out to be one-sided: the Holocaust is a genocide but no other genocide is the Holocaust. The category of genocide was, first of all, introduced into international circulation by a Polish lawyer of Jewish origin Rafał Lemkin during the final decade before the outbreak of World War Two. Genocide has become an almost universally acknowledged term, reinforced by the UN declaration of 1947. Mass crimes occurred in human history since the time immemorial. However, their character fundamentally changed with the advent of modernity, when powerful nation states within the framework of ideological postulates managed to give a new dimension to their politics, the one including actions meted out against entire communities: ethnic groups or nations. The Nazi crime of the Holocaust seems to be a unique exemplification of "modernity" (the term introduced in this sense by Zygmunt Bauman), that is, the combination of technicalisation and mass production with strong bureaucratic structure, which resulted in an unimaginable deed of murdering millions of Jews while utilising technical methods. The killing took a form of "production tasks," which made the moral problems of responsibility and guilt appear in a different light. In the article an attempt is made to show implications stemming from the acceptance of the Holocaust's uniqueness as "a perfect genocide," both in its political and social as well as philosophical and moral dimensions.

KEY wORDs: Holocaust, genocide, Jews, extermination, modernity 


\section{Wstęp}

Jean-Paul Sartre w roku 1968 na odbywającym się w duńskiej miejscowości Roskilde posiedzeniu drugiej sesji Międzynarodowego Trybunału do spraw Zbrodni Wojennych przedstawił raport dotyczący mordu ludności dokonującego się w Wietnamie i próbował wykazać, że ludobójstwo jest równie stare jak ludzkość, gdyż wpisuje się w jej dzieje. Zdaniem Sartre’a swą pełną formę osiągnęło jednak w epoce kolonializmu i związane było ze świadomym działaniem cywilizacji zachodniej, dla której ludobójstwo i eksterminacja stały się narzędziami do opanowania i ekonomicznej eksploatacji różnych części świata ${ }^{1}$. Pomijając zdecydowanie antyzachodni (antyamerykański) wydźwięk wywodów Sartre’a, warto zwrócić uwagę, że autor ten ukazał ważny problem dotyczący masowego mordu, który szczególnego znaczenia nabiera w kontekście nazistowskiej zagłady Żydów w czasie drugiej wojny światowej. Okazuje się bowiem, że zasadniczo ludobójstwo jest kategorią powszechną, dzięki której próbuje się klasyfikować i nazywać różnoraką przemoc stosowaną przez pewne grupy ludzi wobec innych grup, w tym również przez państwa. Nazwanie więc jakiegoś działania ludobójstwem prowadzi raczej do wskazania na jego powszechny charakter, wykluczający wyjątkowość. Kwestia ta dotyczy szczególnie Holokaustu. W gronie badaczy istnieje pogląd o unikalności tej zbrodni, a co za tym idzie - o jej specyficznym usytuowaniu w dziejach ludzkości. Z tego faktu zaś wynikają ważne konsekwen$c_{j e}^{2}$. Jednak istnieje także opinia, że Zagłady, pomimo iż przerażającej w swych rozmiarach, nie można traktować jako wyjątkowego wydarzenia, ponieważ w rezultacie prowadzi to do obniżenia rangi licznych masowych zbrodni dokonanych $\mathrm{w}$ różnych okresach historycznych na innych narodach, grupach etnicznych czy wspólnotach. W takiej perspektywie umniejsza się cierpienia innych ofiar niż Żydzi i w rezultacie odbiera się również prawo do pamięci o innych zbrodniach niż Szoa. Wydaje się, że problem dotyczy poprawnego definiowania zjawiska masowych mordów, a co za tym idzie - właściwego ich zrozumienia. Zasadne będzie w tej sytuacji postawienie pytania o Holokaust jako ludobójstwo i usytuowanie go w kontekście innych masowych zbrodni.

W prezentowanym tekście chciałbym odnieść się do tego zagadnienia i w dużym skrócie pokazać miejsce Zagłady wśród innych ludobójstw, a przede

${ }^{1}$ Por. J.-P. SARtre: Genocide. "New Left Review" 1968, 1/48, s. 11-21. Według autora tekst ten jest wymierzony głównie przeciwko amerykańskiej interwencji w Wietnamie.

${ }^{2}$ Trudno tu nawet w przybliżeniu wskazać najważniejszych badaczy Zagłady, którzy reprezentują taki pogląd lub których stanowisko może być tak interpretowane. Wydaje się, że najlepiej odwołać się do monumentalnego dzieła Raula Hilberga. W rozdziale pierwszym pod tytułem Precedensy autor zarysowuje ten problem, odwołując się do historii niemieckich prześladowań Żydów. Zob. R. Hilberg: Zagłada Żydów europejskich. T. 1. Przeł. J. GiebuŁtowicz. Warszawa 2014, s. 1-28. 
wszystkim jej wyjątkowy charakter. Pominę często przywoływane argumenty i skupię się na tym, że Holokaust jako zbrodnia ludobójstwa, mająca swoje odniesienia w dziejach, w najpełniejszy sposób zrealizował to, co każde tego typu działanie $\mathrm{w}$ sobie zawiera, to znaczy $\mathrm{w}$ największym stopniu wypełnił zaplanowaną intencję realnymi działaniami. W przypadku Szoa doszło więc do szczególnej w dziejach sytuacji: po raz pierwszy udało się zrealizować to, co zaplanowano. Nie chodzi wyłącznie o liczby i konkretne działania, ale o wymiar formalny zbrodni. Wydaje się, że na tym argumencie można oprzeć pogląd o wyjątkowości Holokaustu. Taki punkt widzenia daje możliwość pogodzenia spornych stanowisk, ponieważ z jednej strony bez wątpienia uznaje się Zagładę za ludobójstwo i tym samym nie wyróżnia się jej na tle innych tego typu zbrodni, jednak z drugiej strony opisuje się również jej unikalny charakter.

W celu realizacji wskazanego zamierzenia podzieliłem tekst na trzy części: pierwszą, która krótko charakteryzuje samo zjawisko ludobójstwa, tak jak zdefiniował je twórca tego pojęcia Rafał Lemkin; część drugą, w której chciałbym pokazać, jakiego typu mordem masowym jest Holokaust; oraz część trzecią, w której zwracam uwagę na wyjątkowość Zagłady jako ludobójstwa doskonałego.

\section{Od aktów barbarzyństwa i wandalizmu do ludobójstwa Koncepcja Rafała Lemkina}

Powszechnie wiadomo, że samo pojęcie ludobójstwa pojawiło się w czasie drugiej wojny światowej. Jego twórca jest polski Żyd, prawnik Rafał Lemkin. Po raz pierwszy użył on tego sformułowania w angielskiej wersji - genocide - w 1944 roku, w książce pod tytułem Axis Rule in Occupied Europe... ${ }^{3}$. Należy przy tym pamiętać, że Lemkin dekadę wcześniej zaproponował przyjęcie w ramach prawa międzynarodowego nowej kategorii przestępstwa odnoszącego się do działań państwa, które określił jako „akty barbarzyństwa” oraz „akty wandalizmu”. Autor swoją propozycję przedstawił na V Międzynarodowej Konferencji w sprawie Unifikacji Prawa Karnego (Fifth International Conference for Unification of Penal Law), która odbyła się w Madrycie w dniach 14-20 października 1933 roku. Za pomocą terminów „barbarzyństwo” i „wandalizm” Lemkin próbował

${ }^{3}$ R. Lemkin: Axis Rule in Occupied Europe: Laws of Occupation, Analysis of Government, Proposals for Redress. Washington 1944, s. 79-95. We wskazanym miejscu autor szczegółowo przedstawia swoją koncepcję ludobójstwa, łącznie z uzasadnieniem nazwy. Polski przekład tego dzieła: Tenże: Rządy państw Osi w okupowanej Europie. Prawa okupacyjne, analiza rządzenia, propozycje zadośćuczynienia. Przeł. A. Bieńczy k-Missala i in. Warszawa 2013.

${ }^{4}$ Przedstawiona przez Lemkina propozycja została odrzucona. Niemniej autor opublikował przygotowany przez siebie dokument w niemieckiej wersji pod tytułem: Akte der Barbarei und 
nazwać organizowane przez państwo negatywne działania skierowane przeciwko członkom narodów lub pewnych grup.

Według autora akty barbarzyństwa obejmowały szeroką gamę działań wymierzonych przeciwko jednostkom. Zaliczał do nich powszechnie znane zjawisko niewolnictwa i handlu ludźmi, które prowadziło do dehumanizacji oraz traktowania jednostki jako towaru. Lemkin podkreślał fakt, że struktury państwowe sankcjonowały niewolnictwo i rozumiały je jako naturalny element mechanizmu gospodarczego. Podstawy takiego działania państwa opierały się na założeniu, że niektóre zbiorowiska ludzi wykazujące się specyficznymi cechami fizycznymi i stojące na niższym poziomie cywilizacyjnym z natury przynależą do grupy niewolniczej ${ }^{5}$. W dalszej części pracy omawiającej akty barbarzyństwa autor zwracał uwagę na inne działania wymierzone przeciwko jednostce, których charakterystyczną intencją były represje niewynikające z wrogości przeciw niej, ale podjęte wobec niej ze względu na niszczycielskie cele wymierzone przeciw wspólnocie, grupie czy też narodowi. Lemkin sygnalizował, że owe intencje mogą być zasadniczo różne: religijne, kulturowe, polityczne, gospodarcze, lecz ich wspólną cechą charakterystyczną jest uderzanie $\mathrm{w}$ daną grupę poprzez działanie wobec jej członków 6 . Autor podkreślał międzynarodowy wymiar takich działań. Był przekonany, że wskazane akty barbarzyństwa nie mogą być traktowane jako wyłącznie sprawy wewnętrzne lub o regionalnym zasięgu, lecz winny pozostawać w centrum uwagi wspólnoty

des Vandalismus als "delicta juris gentium“. Tekst ukazał się w grudniu 1933 r. w poczytnym piśmie „Anwaltsblatt Internationales“ (19. Jahrgang, Heft 6). Był to miesięcznik poświęcony zagadnieniom prawnym, wydawany w Wiedniu przez Rudolfa Brauna.

${ }^{5}$ „Untersuchen wir die ratio legis solcher Delikte, wie den Sklaven-, Frauen- und Kinderhandel, so finden wir, daß diese ratio vorwiegend im Postulate der Humanität gelegen ist. Vor allem gilt es hier, die Freiheit und Würde des Menschen in Schutz zu nehmen, zu verhindern, daß der Mensch als Ware behandelt werde" (tamże; we wszystkich cytatach z tego tekstu zachowano pisownię oryginału; w miesięczniku brak numeracji stron).

${ }^{6}$ „Das Leben bringt jedoch, wie wir zur Zeit konstatieren können, Kriminalitätsformen hervor, die beide Elemente, Eingriff in die Individualsphäre des Menschen und auch in die Sphäre des sozialen Zusammenwirkens der Kulturmenschheit, in sich vereinen und genug bedeutsam sind um eine Reaktion der gesamten Welt wachzurufen. Es sind diese Verletzungen des Individuums in seiner Eigenschaft als Mitglied einer Gemeinschaft. Der Wille des Täters geht nicht allein dahin, den Menschen zu verletzen, es soll im gleichen Maß die Gruppe, der die Einzelperson angehört, in derselben und durch dieselbe getroffen werden. Nicht die Menschheitsrechte des Individuums allein, auch die Grundlagen des sozialen Zusammenlebens der Menschheit sind Opfer dieser Straftaten: Hieher gehören vor allem alle auf die Ausrottung ethnischer, nationaler, konfessioneller, sozialer Menschheitsgruppen gerichteten Vergewaltigungen, mögen dieselben politischen, religiösen oder sonstigen Beweggründen entspringen, wie Massacres, Pogrome, Zwangsinternierungen, wirtschaftliche Vernichtungsmaßnahmen u. dgl. barbarische Akte, die gegen das Leben und die körperliche Unversehrtheit, gegen die persönliche Freiheit und die wirtschaftliche Existenzmöglichkeit des Menschen gerichtet sind“" (tamże). 
międzynarodowej, gdyż zagrażają całej ludzkości. Uzupełnieniem prezentowanych działań barbarzyńskich są akty wandalizmu, niewymierzone bezpośrednio $\mathrm{w}$ ludzi, ale związane z grabieżą oraz niszczeniem dóbr materialnych będących własnością poszczególnych członków grupy oraz ogólnie pojętych dóbr kultury, w tym dorobku intelektualnego danej nacji. Autor podkreślał, że omawiane działania mają charakter planowy i systematyczny, wpisują się zatem $\mathrm{w}$ realizację szeroko zakrojonej intencji wyniszczenia danej grupy ${ }^{8}$. Ostatecznie Lemkin zaproponował przyjęcie trzech artykułów, które mogłyby stać się podstawą międzynarodowej konwencji. Odwoływał się przy tym do istniejącej już i akceptowanej reguły prawa międzynarodowego związanej z osądzaniem działań militarnych podejmowanych przeciwko cywilom i jednostkom w czasie konfliktów zbrojnych, powszechnie znanej jako konwencje haskie z lat 1899 i 1907. Artykuły Lemkina bez wątpienia stały się podstawą sformułowanej dekadę później propozycji określenia zbrodni ludobójstwa9. Przede wszystkim

7 „Die gegen Gemeinschaften gerichteten Aktionen sind nicht lediglich Gemeingefahr (danger commun), sie sind eine Weltgefahr (danger general international) durch die Ansteckbarkeit sozialer Psychosen. Von ihrem Wesen ist die dauernde Bedrohung der Menschheit untrennbar. Wird doch der verbrecherische Erfolg einer gegen Kollektivitäten gerichteten Aktion nicht durch eine Einzelhandlung, sondern im Wege andauernder, systematischer Außerrechtsetzung erreicht. [...] Nicht zuletzt sei auf die wirtschaftlichen Schäden solcher verbrecherischer Anschläge auf die Interessen der Menschheit hingewiesen" (tamże).

8 „Der Extreminationskampf gegen Kollektivitäten kann auch seinen Ausdruck finden in der planmäßigen Zerstörung von Werken, in denen sich die geistige Leistungsfähigkeit der Gemeinschaft auf dem Gebiete der Wissenschaft, Kunst oder Literatur offenbart. Der Beitrag jeglicher Gemeinschaft zur Gesamtkultur bildet unbeschadet aller Besonderheiten der Einzelkulturen, um unveräußerliches Gemeineigentum der Menschheit. Die Zerstörung einzelner nationaler Kulturwerke muß als Vandalismus gegenüber dem internationalen Kulturgut angesehen werden. Der Täter fügt nicht bloß einen nicht wieder gutzumachenden Schaden dem Privateigentümer des zerstörten Gutes und der unmittelbar betroffenen Kollektivität, der der Privateigentümer angehört oder deren Geist das Werk entsprungen ist, zu; er schädigt die ganze zivilisierte Menschheit. Die Zerstörung einzelner nationaler Kulturwerke muß als Vandalismus gegenüber dem internationalen Kulturgut angesehen werden. Der Täter fügt nicht bloß einen nicht wieder gutzumachenden Schaden dem Privateigentümer des zerstörten Gutes und der unmittelbar betroffenen Kollekttivität, der der Privateigentümer angehört oder deren Geist das Werk entsprungen ist, zu; er schädigt die ganze zivilisierte Menscheit“" (tamże).

9 "Art. 1. Wer aus Haß gegen eine rassenmäßige, konfessionelle oder soziale Gemeinschaft, oder zum Zwecke ihrer Ausrottung eine strafbare Handlung gegen Leben, Gesundheit, Freiheit, Würde oder wirtschaftliche Existenz einer solchen Gemeinschaft angehörigen Person unternimmt, wird wegen Verbrechens der Barbarei mit Kerker in der Dauer von [...] bestraft, insofern seine Handlung nicht nach einer strengeren Vorschrift des Strafgesetzbuches einer schwereren Strafe unterliegt. Derselben Strafe unterliegt der Täter, falls seine Handlungen gegen eine Person gerichtet war die ihre Solidarität mit einer solchen Gemeinschaft bekundet hat oder für dieselbe eingetreten ist, ohne ihr selbst anzugehören. Art. 2. Wer aus Haß gegen eine der sub. 1 bezeichneten Gemeinschaften oder zum Zwecke ihrer Ausrottung Kunst- oder Kulturwerke (derselben) vernichtet, wird wegen Verbrechens des Vandalismus mit Gefängnis in der Dauer von [...] bestraft, insofern seine Handlung nicht nach anderen Bestimmungen des Strafgesetzbuches einer 
ich autorowi chodziło o stworzenie kategorii prawnej, która będzie odnosiła się do specyficznych działań organizowanych najczęściej przez państwo w celu całkowitego wyniszczenia jakiejś grupy lub wspólnoty. Ważne przy tym wydawało się Lemkinowi to, aby ludobójstwo rozumieć jako przemoc wymierzoną przeciwko jakiemuś ogółowi, co wyraża pierwszy człon przyjętej przez niego nazwy genocide - genus, czyli 'rodzaj'. Pojęcie ludobójstwa ostatecznie zostało wpisane do prawa międzynarodowego dzięki rezolucji ONZ przyjętej w roku 1948 i ratyfikowanej przez większość państw członkowskich ${ }^{10}$.

\section{Holokaust i ludobójstwo - droga do wyjątkowości}

Znamienne, że opisane rozumienie ludobójstwa dla wielu wydaje się nie do zaakceptowania, ponieważ wyklucza jako ludobójcze wiele zbrodni dokonanych w historii ludzkości. Największym zarzutem wydaje się, poza jurysdykcyjnym określeniem masowego mordu, wyłączenie z definicji niezwykle ważnej kategorii, która w dużym stopniu wpływa na jego rozumienie. Krytycy zwracają mianowicie uwagę na brak kategorii politycznej, to znaczy pominięcie w definicji ludobójstwa intencji politycznych. Najogólniej, chodziłoby o to, aby w tej definicji uwzględniać jako przyczynę (przynajmniej jedną z przyczyn) motywację opartą na realizacji pewnych postulatów politycznych. Innymi słowy, ludobójstwo

strengeren Strafe unterliegt. Art. 3. Die in den obenstehenden Artikeln bezeichneten Strafhandlungen werden vom Staate, in welchem der Täter ergriffen worden ist, verfolgt und bestraft, unabhängig vom Orte der vollbrachten Tat und der staatlichen Zugehörigkeit des Täters" (tamże).

109 grudnia 1948 r. Zgromadzenie Ogólne Narodów Zjednoczonych przyjęło dokument pod nazwą „Konwencja w sprawie zapobiegania i karania zbrodni ludobójstwa”. Najogólniej mówiąc, dotyczył on czynów dokonywanych wobec grupy (genos) ludzi. Owe czyny zostały zestawione w następujących punktach: a) zabójstwo dokonane na członkach grupy, b) spowodowanie poważnego uszczerbku ciała lub zdrowia psychicznego członków grupy, c) zamierzone stworzenie warunków, które w konsekwencji spowodują całkowite lub częściowe wyniszczenie fizyczne grupy, d) stosowanie środków, które w zamiarze mają przynieść wstrzymanie urodzin w obrębie grupy, e) przymusowe przekazywanie dzieci z jednej grupy członkom innej grupy. Zawartość tekstu została nieco przeze mnie zmieniona. Oficjalny polski tekst konwencji zob. Konwencja w sprawie zapobiegania i karania zbrodni ludobójstwa uchwalona przez Zgromadzenie Ogólne Narodów Zjednoczonych dnia 9 grudnia 1948 roku (ratyfikowana zgodnie z ustawa z dnia 18 lipca 1950 r.). „Dziennik Ustaw” 1952, nr 2, poz. 9. Oryginalny tekst najłatwiej znaleźć na oficjalnej stronie UNCHR: www.hrweb.org/legal/genocide.html [data dostępu: 7.06.2019]. Jak widać, konwencja bardzo szeroko rozumie pojęcie strony chronionej. Zdefiniowano ją w kontekście polityczno-kulturowym jako naród, grupę etniczną, w znaczeniu biologicznym jako rasę, a także w rozumieniu religijnym. W tym ujęciu wydaje się, że konwencja nie rozstrzyga tego, czym kieruje się sprawca, definiując represjonowaną grupę, lecz ściśle określa karalność w zakresie jego intencji. 
może być popełniane w imię realizacji planów politycznych, czy będzie to na przykład walka klasowa charakterystyczna dla sowieckiego reżimu, czy też idea Lebensraum pojawiająca się $\mathrm{w}$ działaniach nazistów. Wyłączenie intencji politycznej z definicji eksterminacji ma swoje ściśle określone przyczyny i uzasadnienie, odrzuca bowiem rozumienie jako ludobójstwa wszelkich aktów masowych mordów przeprowadzonych przez światowe reżimy z pobudek ideologicznych. Oczywiście na myśl przychodzą tu głównie zbrodnie dokonywane przez reżimy komunistyczne, $\mathrm{z}$ sowieckim na czele. $\mathrm{W}$ warunkach powojennych, wobec rodzącego się w Europie konfliktu dwóch systemów społeczno-politycznych, kompromis związany $\mathrm{z}$ wykluczeniem $\mathrm{z}$ definicji ludobójstwa intencji politycznych wydawał się konieczny. Zwrócił na to uwagę na przykład Konstanty Gebert, wskazując, że pojęcie to jest wysoce umowne, a co za tym idzie - wybiórcze i podporządkowane bardziej czy mniej jawnym celom politycznym, które, jego zdaniem, sprowadzały się do tego, że lata, kiedy opracowano i przyjęto konwencję, traktowane były jako ostatni możliwy moment osądzenia oraz skazania zbrodniarzy nazistowskich, a to musiało się odbyć na drodze kompromisu ze Związkiem Radzieckim ${ }^{11}$.

Główną zasadą prawnej kategorii ludobójstwa jest wskazanie intencji eksterminacji określonej grupy ludzi przy udziale aparatu państwowego. Pomija się przy tym liczbę ofiar oraz niezwykle ważne kryterium społeczne (i oczywiście wskazane wcześniej polityczne). Zdaniem Konstantego Geberta intencjonalny charakter międzynarodowej definicji ludobójstwa powoduje, że za takowe można uznać tylko cztery wydarzenia w historii świata: masową zagładę Hererów dokonaną przez wojska niemieckie w latach 1905-1907, eksterminację Ormian przez Turków w czasie pierwszej wojny światowej, zagładę Żydów, Romów i Sinti przez nazistów w czasie drugiej wojny światowej oraz masową zbrodnię dokonaną przez plemię Hutu na plemieniu Tutsi w 1994 roku w Rwandzie. Wszystkie pozostałe zbrodnie nie kwalifikują się jako ludobójstwo w sensie prawnym, co oczywiście prowadzi do wielu wątpliwości i budzi silny sprzeciw $^{12}$. W tym kontekście pojęcie to przyjmuje trzy zakresy znaczeniowe. Pierwszy odnosi się do wspomnianej ONZ-owskiej definicji określającej kilka działań wobec jakiejś grupy. Drugi zakres znaczeniowy ma intuicyjny i przez

${ }^{11}$ Zob. K. Gebert (D. Warszawski): Nazywanie nieszczęścia. „Polityka” 2009, nr 45, s. 32-33. Podaję za: M. Miniszewski: Architektura zła. Wyjątkowość Holokaustu jako problem filozoficzny. Kęty 2012, s. 36-37.

${ }^{12}$ Zob. K. Gebert (D. Warszawski): Nazywanie nieszczęścia..., s. 32. Podaję za: M. MiNiszewski: Architektura zła..., s. 38. Wątpliwości jest wiele. Inni badacze znacznie poszerzają listę ludobójstw, szczególnie w odniesieniu do współczesności. Zagadnienie to w kontekście definiowania samego terminu genocide dobrze omawia, opierając się na obszernej literaturze, Uriel TAL, zob. Tenże: On the Study of the Holocaust and Genocide. In: The Nazi Holocaust. Historical Articles on the Destruction of European Jews. Ed. M.R. MArrus. Vol. 9: The End of the Holocaust. London 1989, s. 179-196. 
to szerszy charakter, gdyż określa jako ludobójstwo każdą zbrodnię masową (może tu pojawić się kryterium liczbowe) skierowaną przeciwko grupie ludzi ze względu na przypisywane jej cechy. Jest to definicja najszersza, ale też chyba najbliższa powszechnej akceptacji, wyrażająca pewne odczucie znane każdemu. Wreszcie trzecie znaczenie odwołuje się do politycznego definiowania ludobójstwa, co pozwala określić, które zbrodnie historyczne nim są. Ostatnie rozumienie wydaje się najważniejsze, gdyż determinuje to, co jest najbliższe istocie tego zjawiska nie tylko $\mathrm{w}$ wymiarze formalnym oraz przyczynowym, lecz może przede wszystkim moralnym (nie znaczy to jednak wcale, że dwa poprzednie zakresy znaczeniowe czynnika moralnego nie uwzględniają). Najważniejszą rolę odgrywają tutaj szczególny interes polityków i polityczna konfrontacja między państwami lub narodami. Badacze podkreślają, że w politycznym sensie istnieje ciekawy aspekt definiowania ludobójstwa, ponieważ z jednej strony pojawia się tendencja do traktowania tej zbrodni maksymalnie szeroko i to stanowisko reprezentowane jest przez faktyczne bądź ewentualne ofiary, z drugiej zaś strony władze państwowe, stanowiące realnych lub potencjalnych agresorów, dążą do maksymalnego zawężania znaczenia, co ma wykluczać przypisywanie ich działaniom znamion ludobójstwa. Nie ulega wątpliwości, że takie ujęcie otwiera pole do wielu nadużyć.

Świadomość różnych zakresów znaczeniowych omawianego pojęcia pozwala właściwie odnieść się do zagadnienia nazistowskiej zbrodni dokonanej na Żydach w czasie drugiej wojny światowej i przyjrzeć się kwestii jej wyjątkowości. Chciałbym zwrócić uwagę na konsekwencje przyjęcia lub odrzucenia szczególności Holokaustu na tle innych zbrodni ludobójstwa. W powszechnym odbiorze społecznym ujęcie zagłady Żydów jako wydarzenia unikalnego i bezprecedensowego w dziejach prowadzi do uznania Szoa za zbrodnię przekraczającą wszystkie, której z tego względu należy się wyjątkowe miejsce w pamięci całej ludzkości, co oczywiście wiąże się także z odpowiednim szacunkiem dla ofiar oraz - co ważne - ich potomków. Bezpośrednio łączy się z tym również niewypowiedziane wprost, ale założone, gradacyjne traktowanie aktów ludobójstwa i w rezultacie uznanie wszystkich pozostałych za mniej istotne, zarówno tych, które już miały miejsce w historii, jak i tych, które mogą się zdarzyć. Zwolennicy wyjątkowości Holokaustu podkreślają szczególnie ogrom cierpienia, który przyniósł, i z tego powodu też żądają wyraźnego oraz stanowczego potępienia tej zbrodni. Brak takiej reakcji uznawany jest w niektórych przypadkach za pewną formę akceptacji nazistowskiego mordu. Z kolei przeciwnicy wyjątkowości Szoa próbują w pewien sposób zrzucić z ludzkości a $\mathrm{w}$ zasadzie z cywilizacji zachodniej - poczucie winy, co sprowadza się do niezwykle trudnego zagadnienia odpowiedzialności za żydowską eksterminację nie tylko nazistów jako bezpośrednich sprawców, ale również wielu kolaborujących z nimi podbitych narodów bądź pozostałych nacji z „wolnego świata", które wykazały się zastanawiającą biernością wobec tej zbrodni, co 
w łagodnej formie można określić jako obojętność, w mocniejszej zaś nawet jako przyzwolenie ${ }^{13}$. Reasumując - przy pełnej świadomości pewnego uproszczenia - dyskurs o wyjątkowości Holokaustu można ująć w kategoriach samorozliczenia (czy też samorozgrzeszenia) dużej części ludzkości ze swego niechętnego stosunku do Żydów, co ma nie tylko historyczne znaczenie, ale odnosi się do współczesności i kształtowania własnej tożsamości narodowej czy wspólnotowej. Szoa pozostaje przez to niewygodnym wydarzeniem, budzącym poczucie winy, wyraźną skazą na troskliwie formowanym micie narodów oraz ogólnie cywilizacji zachodniej ${ }^{14}$.

Wobec przedstawionych założeń można powiedzieć, że próba ujęcia i zrozumienia zjawiska Holokaustu dotyka kreowania własnej tożsamości przez poszczególne wspólnoty (zarówno samych Żydów, jak i innych), a w szerszym znaczeniu może służyć nawet do określania kondycji ludzkiej oraz pesymistycznego namysłu nad naturą człowieka i jego skłonnością do czynienia bezgranicznego zła („banalnością zła”, jak określała to Hannah Arendt) ${ }^{15}$. Zagłada stała się także bardzo dobrym narzędziem mocnej krytyki cywilizacji i jej rozwoju w kierunku nowoczesności, ponieważ zmiany te zachodzą w społeczeństwach kosztem niwelowania etycznego wymiaru życia i relacji między ludźmi. Są już powszechnie znane ciemne strony postępującej technicyzacji, masowości oraz

${ }^{13}$ To kwestia niezwykle skomplikowana i w zasadzie otwarta. Warto zaznaczyć, że taki stosunek do eksterminacji Żydów w okupowanej Europie należy oddzielić od aspektu epistemologicznego. Często bowiem szczególnie przywódcy zachodniego świata tłumaczyli się, że o zbrodni nie wiedzieli. W świetle badań wydaje się, że argument ten jest nie do utrzymania. Innym problemem pozostaje kwestia posiadania wiedzy, ale nieprzyjmowania faktów do wiadomości, gdyż po prostu wymykają się one racjonalnym standardom obowiązującym w danym kręgu kulturowym, innymi słowy - w fakty te trudno uwierzyć. Kolejnym ważnym zagadnieniem jest uświadomienie sobie, że opisywany zarzut obojętności lub nawet kolaboracji można postawić również części przywódców diaspory europejskiej, a także pozaeuropejskiej. Pierwszą bodaj osobą, która odważyła się zwrócić na to uwagę w publicznym dyskursie, była Hannah Arendt. Spotkała się w związku z tym z wielką krytyką intelektualnych przywódców społeczności żydowskiej, na przykład ze strony Gershoma Scholema.

${ }^{14}$ Problem winy i uwikłania jest bardzo obszerny oraz wielowątkowy. W kontekście filozoficznym pierwszy poruszył go Karl Jaspers w swym słynnym tekście Die Schuldfrage. Wśród wielu wątków chciałbym przywołać ten związany z brakiem odpowiedniej reakcji aliantów na doniesienia o żydowskiej eksterminacji. Chodzi mianowicie o to, że z militarnego punktu widzenia alianci mieli możliwość zatrzymania ludobójstwa za pomocą moralnie wątpliwych lotniczych bombardowań obozów koncentracyjnych. Nic takiego jednak nie nastąpiło. Wśród wielu pozycji dotyczących tego zagadnienia chciałbym wskazać na wywody następujących autorów: M. GILBerT: The Question of Bombing Auschwitz. In: The Nazi Holocaust..., s. 249-305; D.S. Wyman: Why Auschwitz Was Never Bombed. In: The Nazi Holocaust..., s. 306-331; B. LANG: Philosophical Witnessing. The Holocaust as Presence. Waltham 2009, s. 57-74.

${ }^{15}$ H. AREndt użyła tego określenia w słynnej książce Eichmann in Jerusalem. A Report on the Banality of Evil. New York 1963 (polski przekład: TAŻ: Eichmann w Jerozolimie. Rzecz o banalności zła. Przeł. A. Szost Kiewicz. Kraków 1987). 
nacisku na konsumpcyjny tryb życia ${ }^{16}$. Wszystko to sprawia, że człowiek traci swoje humanitas i staje się trybem maszyny społecznej, konsumentem określonych dóbr, czy też mówiąc przewrotnie - produktem nowoczesnej cywilizacji.

Już w prezentowanych przykładach można dopatrzyć się wyjątkowości Holokaustu ${ }^{17}$, niemniej chciałbym jeszcze przywołać inny aspekt tej zbrodni, mogący składać się na jej szczególność, a zarazem łączący się z ludobójstwem. Analizując związek Szoa z ludobójstwem, należy uznać fakt, który nie budzi żadnych wątpliwości. Jeśli mogę się tak wyrazić, to relacja Holokaust - ludobójstwo jest relacją semantycznie asymetryczną. To znaczy, że Holokaust jest ludobójstwem, lecz synonimicznie inne ludobójstwa nie są holokaustami. Zatem nie można tych nazw stosować zamiennie, co w dyskursie współczesnym często się dzieje ${ }^{18}$. Na czym owa różnica mogłaby polegać? Wydaje się, że w odpowiedzi na to pytanie może pomóc odniesienie Zagłady do innych genocydów, można też oczekiwać, że to porównanie ewentualnie wskaże kolejny trop w kwestii jej wyjątkowości.

Jeden z najbardziej znanych badaczy Holokaustu, Berel Lang, zwraca uwage na ważny fakt: nie chodzi wyłącznie o wyznaczenie typologii ludobójstwa, które mogą służyć oszacowaniu skali działań i osądzeniu odpowiedzialności w konkretnych przypadkach zbrodni, nie chodzi także wyłącznie o ustanowienie stopni ludobójstwa, czyli pewnej aksjologizacji zjawiska, ale o prawidłowe zbadanie i wyznaczenie różnych cech, które charakteryzują ludobójstwo. Ich

16 Zjawisko to zostało trafnie podsumowane w: A. Milchman, A. Rosenberg: Eksperymenty w myśleniu o Holocauście. Auschwitz, nowoczesność i filozofia. Przeł. L. Krowicki, J. SzAcki. Warszawa 2003. Zob. szczególnie rozdział II: W obliczu paradoksu postmodernizmu i Holocaustu (s. 50-84).

17 Historyczną doniosłość Holokaustu - i tym samym jego wyjątkowość - można określić następująco: „Istnieją wydarzenia historyczne, które niszczą tkankę cywilizacyjną, które radykalnie przekształcają samą konstrukcję matrycy społeczno-kulturowej. Holocaust, symbolizowany przez dymy Auschwitz [...], był właśnie takim wydarzeniem” (tamże, s. 11). Nieco inaczej wyjątkowość Zagłady ujmuje wybitny badacz Yehuda Bauer, który m.in. wiąże ją z główną przyczyną wywołanej przez Hitlera wojny światowej. W jednym ze swych tekstów, podsumowując problem, pisze: „What was unique in the Holocaust was the totality of its ideology and of its translation of abstract thought into planned, logically implemented total murder. More than that - it became a central part of the rationale for a total war that caused some 35 million casualties in the six-year long struggle. That is uniqueness of the Holocaust" (Y. BAuER: The Place of the Holocaust in Contemporary History. In: The Nazi Holocaust. Historical Articles on the Destruction of European Jews. Ed. M.R. Marrus. Vol. 1: Perspectives on the Holocaust. London 1989, s. 226).

18 Można spotkać się z poglądami, w których mianem holokaustu określa się nie tylko negatywne i zbrodnicze akty, ale także różne współczesne działania. Na przykład w wielu teoriach spiskowych za holokaust uznaje się ukryte działania podejmowane przez rządzących światem, związane z zamiarem doprowadzenia do globalnej katastrofy klimatycznej; można też spotkać się z nazwaniem obowiązku szczepień ochronnych holokaustem dzieci. Trafne przykłady opisane są w: A.H. Rosenfeld: Kres Holokaustu. Przeł. R. Czenalska, A. Kuczkiewicz-Fraś. Kraków 2013, s. 37-50. Autor odnosi się do tego zjawiska, określając je mianem wiktymizacji. Wskazuje m.in., że wyjątkowość Holokaustu polega na tym, że zbrodnia ta, niosąc w sobie pierwiastek unikalności, jeśli zostanie przypisana innym działaniom, przyczyni się do podniesienia ich rangi. 
wyróżnienie prowadzi do określenia istoty tego zjawiska, a to, zdaniem autora, jest niezbędnym etapem „przy konstruowaniu społecznych lub politycznych modeli służących jego [Holokaustu - J.S.] przewidywaniu lub zapobieganiu”19. Uwaga powinna być zatem skupiona na odpowiedzi na „proste” pytanie: czym był (jest) Holokaust? Czyli o określenie jego istoty.

Jak wiadomo, rozważania o istocie prowadzą w stronę poznania konstytutywnych właściwości czy też cech danego poznawanego zjawiska (lub rzeczy). Jest to o tyle ważne, że istota-essentia wyróżnia to, co określa, i na dodatek wyróżnia to $\mathrm{w}$ podwójnym znaczeniu: z jednej strony wskazuje na niepowtarzalność tego, co określane, i w tym znaczeniu wszystko, co istnieje lub może zaistnieć jako jednostkowe, jest niepowtarzalne, zatem także w pewnym sensie wyjątkowe; z drugiej strony określanie istoty skazane jest na przyjęcie pewnych zrelacjonowanych względem siebie ogólników, co sprawia, że określenie istoty zawsze wskazuje też na to, co wspólne pewnej grupie zjawisk, rzeczy, przedmiotów ${ }^{20}$. Wedle tej miary Holokaust był wydarzeniem wyjątkowym jako jednostkowa zbrodnia, ale równocześnie nie był wyjątkowy, a przede wszystkim niepowtarzalny, ponieważ może być i jest porównywany do innych masowych zbrodni, które zdarzyły się w historii, oraz do tych, które nastąpią, ponieważ nie sposób wykluczyć możliwości zaistnienia równie przerażającego wydarzenia w przyszłości. Berel Lang ujął to w prostym stwierdzeniu: „[...] skoro ludobójstwo zdarzyło się raz, może wydarzyć się po raz drugi" ${ }^{21}$. Wskazał więc, że jeśli Holokaust wydarzył się już w historii, to wydarzenie takie jest możliwe, co prowadzi do wniosku, że charakter, a zatem istota ukazuje możliwości jego zaistnienia. Wiedza o możliwości zaistnienia Szoa sprawia zaś, że ukazuje się sposobność odkrywania lub przewidywania jego pojawiania się w przyszłości, to z kolei daje nadzieję na podjęcie skutecznych działań zapobiegawczych. Zatem rozpatrywanie Holokaustu jako takiego i ujęcie go z perspektywy ludobójstwa wyjątkowego może pełnić prognostyczno-zapobiegawczą funkcję wobec ludzkości, dając człowiekowi narzędzie do przeciwdziałania w przyszłości. Idąc tym tropem, należy przyjąć ową wyjątkowość Zagłady, co jednak nie wpływa na ocenę innych masowych zbrodni, nie obniża rangi innych ludobójstw i nie kwestionuje ich znaczenia.

19 B. Lang: Nazistowskie ludobójstwo. Akt i idea. Przeł. A. Zı̨̨вıŃsKa-Witek. Lublin 2006, s. 33.

${ }^{20}$ Rozważania dotyczące istoty odwołują się do jej filozoficznego i teoriopoznawczego charakteru. Istota-essentia w klasycznym rozumieniu to definicja wskazująca na to, „czym coś jest”. Poznając coś, zawsze do takiego charakteru poznawanego przedmiotu się odnosimy. Zatem pojawia się tu pewien dobrze znany paradoks: poznanie istoty sprowadza się do ujęcia konstytutywnych właściwości tego, co jest - i to dotyczy każdej jednostkowej rzeczy, każdego jednostkowego zjawiska. Niemniej, aby opisać to jednostkowe zjawisko lub rzecz, jesteśmy skazani na posługiwanie się pojęciami ogólnymi, więc przysługującymi wielu zjawiskom czy rzeczom. Ten paradoks dobrze charakteryzuje problem Holokaustu i jego odniesienia do innych ludobójstw.

${ }^{21}$ B. LANG: Nazistowskie ludobójstwo..., s. 34. 
Stąd właśnie taka próba analizowania Holokaustu w odniesieniu do ludobójstwa pozwala uwolnić się od zasygnalizowanych wcześniej dylematów. Można powiedzieć, że w pewien sposób łączy dwa kluczowe dla rozpatrywania wszelkich masowych mordów punkty widzenia: historyczny i etyczny. Wydaje się bowiem, że we wskazanych wcześniej trudnościach w określaniu Holokaustu jako zbrodni wyjątkowej, unikalnej, a co za tym idzie - w pewnym „deprecjonowaniu” innych ludobójstw, wątki historycznej analizy zjawiska oraz jej moralnej konsekwencji determinują oba skrajne stanowiska w sporze. Tymczasem pominięcie ujęć historycznego i etycznego prowadzi do załagodzenia lub nawet do eliminacji polemiki o wyjątkowość Holokaustu. Jednak stanowisko to musi zawierać ważne założenie, mianowicie: że w kontekście etyki i moralności nie mamy do czynienia $z$ istnieniem absolutnych, niezmiennych i ahistorycznych zasad lub praw, lecz raczej z pewnymi kategoriami, które realizują się w konkretnym historycznym czasie i są historycznie zdeterminowane, nawet jeśli przyjmiemy, że nie łączy się to wcale $\mathrm{z}$ ich progresją. Innymi słowy, prawa moralne akceptowane i obowiązujące ludzi zależą od konkretnego czasu historycznego, a także konkretnego otoczenia kulturowego, społecznego i politycznego. Tym samym również akceptowalność pewnych zjawisk jest zawsze zróżnicowana. Dlatego badając je, nawet gdy jednoznacznie należy potępiać dane zjawisko - nikt bowiem nie powinien mieć wątpliwości, że Holokaust lub jakiekolwiek inne ludobójstwo, masowe mordy i wszelkie działania prowadzące do anihilacji ludzi są z zasady złe i nieakceptowalne - to nie zmienia to faktu, że czynnik determinacji historycznej musi być uwzględniony. Oczywiście niesie to $\mathrm{z}$ sobą również ściśle określone konsekwencje w sferze moralnej. Odnosząc się zatem do tych czynników, historycznie rzecz ujmując, ludobójstwo rozumiane jako proces świadomego wyniszczania jakiejś grupy ludzkiej pojawiło się $\mathrm{w}$ dziejach dużo wcześniej, zarówno przed zbrodnią nazistowską, jak i przed jakimikolwiek rozważaniami dotyczącymi tego zjawiska. Edmund Burke trafnie więc zauważył, że wielkie imperia zawsze powstawały i powstają na ludzkiej krwi. W tym stwierdzeniu bez wątpienia nie ma mowy o masowych mordach i eksterminacji jako sposobie osiągania dobrobytu, lecz zasygnalizowany został problem historyczno-etycznego uwikłania. Rafał Lemkin przywołał kilka konkretnych przykładów zbrodni, które z jednej strony wpisują się $\mathrm{w}$ działania wielkich imperiów, z drugiej mają charakter masowy. Są to: masakra dokonana na Żydach przez Tytusa po pierwszym powstaniu żydowskim w Palestynie w 70 roku n.e., zniszczenie Kartaginy przez Rzymian w roku 146 p.n.e., okrucieństwa dokonywane przez Czyngis-chana, następnie w czasach nowożytnych: ludobójcze działania francuskich władz rewolucyjnych przeciwko Wandei oraz zbrodnia dokonana na ogromną skalę przez Turków na Ormianach, ponieważ według szacunków pochłonęła 600 tysięcy ofiar, co, biorąc pod uwagę ówczesne warunki i możliwości techniczne, sprawia, że pod względem liczbowym ten mord śmiało może „konkurować” 
z żydowską Zagładą 22 . Wszystkie te wydarzenia są przytoczone wybiórczo i należy je traktować raczej jako przykłady ludobójstwa niż jego jedyne historyczne egzemplifikacje. Bez wątpienia wszystkie owe zbrodnie są złe i nieakceptowalne, dlatego muszą być analizowane w swoim konkretnym historycznym uwarunkowaniu, zarówno pod kątem przyczyn, jak i skutków, które wywołały. Podczas takich badań można doświadczyć względności oceny moralnej danych wydarzeń, ponieważ z perspektywy „uwikłania” tych mordów w historyczny czas, swoiste problemy społeczno-polityczne czy kulturowe ich postrzeganie staje się relatywistyczne. Tym jednak, co nie powinno ulegać wątpliwości, jest wskazany wcześniej charakter zbrodni, którego cechy obligują do tego, żeby ze współczesnej, a więc również historycznie uwikłanej, perspektywy oceniać te wydarzenia jako ludobójstwa. Tak też został opisany Holokaust - jako ludobójstwo, lecz mieści on w sobie ważny i niemożliwy do wyeliminowania typologiczny aspekt, który może prowadzić w stronę ujęcia Szoa jako zjawiska w historii ludzkości wyjątkowego ${ }^{23}$.

\section{Holokaust - ludobójstwo doskonałe}

Być może problem wyjątkowości zagłady Żydów w Europie najlepiej przedstawił wspomniany Berel Lang. Jak zaznaczyłem wcześniej, po pierwsze, wskazał on na decydujący przy rozpatrywaniu tego zagadnienia czynnik historyczno-moralnego relatywizmu. Po drugie, Lang włożył wiele wysiłku w oczyszczenie całego dyskursu o Szoa z uwikłania w nierozstrzygalne spory oraz uporządkował różne poziomy analizy tego zjawiska. Przede wszystkim

${ }^{22}$ Podaję za: tamże, s. 33. W przypadku zbrodni na Ormianach niektórzy badacze wskazują, że należałoby mówić o etnobójstwie, a nie ludobójstwie. Różnica polega przede wszystkim na tym, że Turcy dawali Ormianom możliwość zmiany wyznania na islam i tym samym uratowania życia. Zagłada w tym przypadku ideologicznie miałaby dotyczyć kultury i religii. Fizyczna eksterminacja była ostatecznością. Dodatkowo koncepcję tę wzmacnia się podkreślaniem faktu, że Turcy przeprowadzili swą zbrodniczą akcję tylko na własnym terytorium. Naziści z kolei dokonali zagłady Żydów głównie na terytoriach okupowanych. Por. Y. BAuer: The Place of the Holocaust..., s. 239-241. Autor ten zarazem zaznacza, że podobieństwa między rzezią Ormian i zagładą Żydów są dużo ważniejsze od różnic: „The differences between the holocaust and the Armenian massacres are less important than the similarities - and even if the Armenian case is not seen as a holocaust in the extreme form which it took towards the Jews, it is certainly the nearest thing to it. On the continuum, the two events stand next to each other" (tamże, s. 241).

${ }^{23}$ Podam jeden ciekawy przykład uzasadnienia wyjątkowości Holokaustu, który formułuje Uriel Tal. Pisze on mianowicie, że dla nazistów Żydzi byli śmiertelnymi wrogami, gdyż ze swoim monoteizmem stanowili „konkurencję" w walce o nowego człowieka w kontekście religijno-kulturowym. Zob. U. TAL: On the Study of the Holocaust..., s. 218. 
Zagłada badana jest $\mathrm{z}$ perspektywy wydarzenia historycznego. Najogólniej mówiąc, sprowadza się to do odpowiedzi na zasadnicze pytanie: czym był (jest) Holokaust? Udziela się jej, odkrywając i opisując jego przyczyny. To historyczne stanowisko nie analizuje charakteru lub istoty zjawiska, lecz pokazuje szczegółowo, jak doszło do wydarzenia, rekonstruuje jego przebieg i w pewnym stopniu również jego konsekwencje. Oddając należny szacunek całemu podjętemu w ten sposób wysiłkowi, Lang zaznaczył, że takie podejście do problemu Holokaustu nie jest w stanie rozstrzygnąć o jego wyjątkowości. Po pierwsze, można stwierdzić trywialnie, że każde zjawisko historyczne jest wyjątkowe, a badanie w tym zakresie powinno jednak dotyczyć zjawisk „bezprecedensowych”"24. Po drugie co wydaje się o wiele ważniejsze - historyczne opisy Zagłady prowadzą do nierozstrzygalnego sporu tzw. fundamentalistów z ,intencjonalistami”, czyli sporu o źródła Holokaustu, pytania o to, czy naziści w osobie Hitlera planowali mord na Żydach od początku i jest on tym samym wpisany w ideologię nazistowską, czy też Zagłada pojawiła się jako skutek zainicjowanego procesu, który właśnie w Holokauście miał swoją ostateczną realizację ${ }^{25}$. Przyjęcie jednego z tych stanowisk ma decydujące znaczenie dla kwestii oceny Szoa jako ludobójstwa, ale także w kontekście winy i osądu odpowiedzialnych za ten mord ${ }^{26}$. Nierozstrzygalność wspomnianego sporu wynika $\mathrm{z}$ tego, że w uzasadnieniu opozycyjnych punktów widzenia przywołuje się historyczne argumenty, to znaczy wskazuje się na poszczególne przyczyny i buduje ich logiczny ciąg, który ma uzasadnić słuszność przyjętego poglądu i zarazem odrzucić przeciwny. Lang próbował odciąć się od tego typu dyskusji, ponieważ, według niego, Holokaust jest rezultatem realizacji pewnego typu „idei”, która ma to do siebie, że choć mieści w sobie intencjonalny charakter, to jednak nie sposób historycznie udowodnić jej „realnego” pojawienia się. Autor pisał po prostu: „Istnieją koncepcyjne i praktyczne trudności w ustaleniu historycznego punktu, w którym intencja

24 B. LANG: Nazistowskie ludobójstwo..., s. 34.

25 Wiele światła na ten problem rzucają ustalenia Saula Friedländera. W jednej z najważniejszych książek poświęconych Holokaustowi w ogóle autor ten, wskazując nierozstrzygalność sporu fundamentalistów z intencjonalistami, sam zwraca zarazem uwagę na znamienny fakt historycznego (w czasie zwanym erą ideologii) pojawienia się pewnych czynników, które sprzyjały zaistnieniu lub ujawniły tę możliwość w ostatecznej formie nazistowskiej zbrodni. Friedländer skupił się mianowicie na czynnikach ideologiczno-kulturowych, które razem z faktami mającymi miejsce w czasie reżimu nazistowskiego i wojny sprawiły, że do zbrodni doszło. Zob. S. Friedländer: Czas eksterminacji. Nazistowskie Niemcy i Żydzi 1939-1945. Przeł. S. KupISZ, A.M. Nowak, K. MasŁowski. Warszawa 2010, s. 13-29.

${ }^{26}$ Lang pisze między innymi: „[...] ta kwestia [założenie funkcjonalnego, a nie intencjonalnego charakteru nazistowskiej zbrodni - J.S.] ma szczególny związek z omawianym tematem z powodu popieranej ostatnio przez niektórych historyków tezy głoszącej, że ludobójstwo na Żydach nie było nigdy szczególnie zamierzone przez nazistów, zaistniało prawie spontanicznie, jako rezultat niepowiązanych z sobą, a więc niesterowanych od góry decyzji” (B. LANG: Nazistowskie ludobójstwo..., s. 35). 
staje się intencją - nawet w przypadku jednostki, nie mówiąc już o grupie lub intencjach zbiorowych" ${ }^{27}$. Zatem w sporze o charakter Holokaustu badania historyczne nie mają większego znaczenia.

Berel Lang podkreślił także, że możliwe do wyznaczenia historyczne przykłady masowych mordów wskazują na konieczność dokonania gradacji w samym pojęciu ludobójstwa. Prowadzi to do wniosku, że jakąkolwiek typologię przyjmiemy - przy zastrzeżeniu, że w żaden sposób nie może ona wpływać na wartościowanie zjawiska masowego mordu, a więc w konsekwencji na uznanie niektórych za „lepsze”, innych zaś za „gorsze” - nie ulega wątpliwości, iż ludobójstwo na przestrzeni dziejów stopniowo nabiera innego charakteru, związanego z cywilizacyjnym postępem, również technicznym ${ }^{28}$. Eksterminacje zatem nasilają się w nowożytności wraz ze zmianą wizji państwa, ponieważ przekształciło ono swój stanowy charakter w silnie scentralizowaną, zbiurokratyzowaną strukturę, która stopniowo przejmowała kontrolę nad kolejnymi obszarami życia społecznego. W takich warunkach ludobójstwo przybierało także nowe formy, co wiązało się ze zwiększającą się możliwością działania przeciw grupom ludzi, przede wszystkim dzięki wprzęgnięciu w mechanizm zbrodni aparatu państwowego oraz różnych gałęzi przemysłu. W tym właśnie część badaczy (Berel Lang, Hannah Arendt, Lucy Dawidowicz, Zygmunt Bauman, Yehuda Bauer) upatruje bezprecedensowość nazistowskiego mordu na Żydach. W stopniu zupełnie wyjątkowym proces eksterminacji Żydów stał się bowiem realizowanym konsekwentnie państwowym celem, w który zaangażowany został cały nazistowski aparat urzędowy ${ }^{29}$. Nie mamy do czynienia $\mathrm{z}$ taką sytuacją $\mathrm{w}$ przypadku żadnego wcześniejszego mordu lub $\mathrm{w}$ wymienionych zbrodniach powojennych oraz innych kwalifikowanych jako ludobójstwo. Zagłada odbyła się w warunkach aktywności całego państwa, które wykorzystało do tego najnowsze osiągnięcia techniczne, sprawiając, że mordowanie Żydów przybrało postać produkcyjną (sławne die Fabrikation der Leichen Hannah Arendt) ${ }^{30}$ i odbyło się w specjalnie wybudowanych w tym celu

27 Tamże.

28 Najogólniej można nazwać to zjawisko „nowoczesnością” - modernity. Koncepcję tę stworzył Zygmunt Bauman, który uważa, że właśnie nowoczesność ze wszystkimi swymi aspektami, a więc postępem technologicznym, rosnącą biurokratyzacją i formalizacją struktur społecznych, umasowieniem produkcji, sprawiła, iż Holokaust jako masowa Zagłada stał się możliwy i został przeprowadzony w takim miejscu i czasie, to znaczy w Niemczech - wysoko rozwiniętym kraju europejskim. Zarazem dla części badaczy w nowoczesności tkwi odpowiedź na pytanie, dlaczego Holokaustu dopuścili się Niemcy. Jest to związane z koncepcją tzw. Sonderweg.

29 Lang wskazuje, że przejawia się tu zasygnalizowany wcześniej charakter Holokaustu, który można określić jako realizację z góry założonej intencji - z zastrzeżeniem jej niemożliwej historycznej weryfikacji.

30 Arendt użyła tego terminu w sławnym wywiadzie udzielonym telewizji ZDF w 1964 r. Polskie tłumaczenie: H. Arendt: Co pozostaje? Günter Gaus rozmawia z Hannah Arendt. Przeł. J. KAŁĄżNy. „Przegląd Polityczny” 2002, nr 55, s. 52-57. M. Miniszewski wskazuje na zły przekład tego wyrażenia na język polski. Tłumacz niemiecki zwrot: die Fabrikation der Leichen, prze- 
„fabrykach śmierci” (Vernichtungslagern). Stąd Bauman powiązał Holokaust z nowoczesnością, wskazując na jego uniwersalny i jednocześnie unikalny charakter. Zagłada Żydów mogła zostać przeprowadzona tylko w warunkach triumfu nowoczesności i nie może dziwić, że zdarzyła się w środku Europy, a dokonał jej wysoko rozwinięty kulturowo i ekonomicznie naród niemiecki. Holokaust należy więc traktować wyjątkowo, lecz owa wyjątkowość wynika raczej z gradacyjnego procesu postępu ogólnocywilizacyjnego, który sprawił, że ludobójstwo, zawsze obecne w ludzkiej historii, mogło teraz przybrać tak wyspecjalizowany i masowy charakter, przy wykorzystaniu państwowej struktury, planowania i ścisłej organizacji produkcji.

Można zatem powtórzyć za Sartre’em, że ludobójstwo jest stare jak świat, ale zmieniło się wraz z nazistowską zbrodnią. Zdaniem Langa przed Holokaustem nigdy nie łączyło ono w pełni intencji i działania, a to znaczy, że nie łączyło tak ściśle idei czy intencji dokonania zbrodni z dokonanym aktem. Natomiast nazistowska próba unicestwienia Żydów powiązała w stopniu niespotykanym zamiar z realizacją. Nawet jeśli ostatecznie nie udało się wymordować wszystkich Żydów (których liczbę w Europie szacowano na około 11,5 mln, jak czytamy w tajnym dokumencie ze spotkania w Wannsee w styczniu 1942 roku ${ }^{31}$, to jednak zbrodnia przybrała powszechny charakter - naziści zdołali przeprowadzić Zagładę również poza swoim państwem ${ }^{32}$. Właśnie to innowacyjne nazistowskie połączenie intencji z realizacją stanowić może o wyjątkowości Holokaustu, który

łożył jako „przerabianie ofiar” (tamże, s. 53), co zupełnie nie oddaje sensu. Właściwy przekład to: „fabrykowanie trupów” lub „produkowanie trupów”. Zob. M. Miniszewski: Architektura zła..., s. 42, przyp. 95. Sformułowania o mordowaniu na skalę przemysłową w komorach gazowych użył w mowie końcowej główny brytyjski oskarżyciel na procesie norymberskim Sir Hartley Shawcross. Powiedział m.in.: "Two-thirds of the Jews in Europe exterminated, more than six million of them on the killers' own figures. Murder conducted like some mass production industry in the gas chambers and the ovens of Auschwitz, Dachau, Treblinka, Buchenwald, Mauthausen, Maidanek and Oranienburg" (Nuremberg Trial Proceedings. Vol. 19: One Hundred and Eighty-Second Day-One Hundred and Eighty-Ninth Day, s. 433. Dostępne w Internecie: https://avalon.law.yale. edu/imt/07-26-46.asp [data dostępu: 11.06.2019]).

${ }^{31}$ Konferencji w Wannsee, która w niemal zgodnej opinii badaczy uważana jest za symbol Zagłady - ostatecznego rozwiązania, poświęconych jest wiele publikacji. Większość zachowanych dokumentów została udostępniona na stronie internetowej Muzeum w Wannsee. Kluczowy wydaje się stenogram ze spotkania sporządzony przez Adolfa Eichmanna. W języku polskim dostępna jest dotycząca konferencji wyczerpująca monografia autorstwa Petera Longericha: Konferencja w Wannsee. Droga do „Ostatecznego rozwiązania”. Przeł. B. Nowacki. Warszawa 2018. Rzeczony protokół wraz z tłumaczeniem i krótkim komentarzem można znaleźć na s. 89-140.

${ }^{32}$ Stąd Lucy Dawidowicz określa Zagładę jako wojnę, którą naziści prowadzili przeciwko Żydom. Zob. najsłynniejszą książkę tej badaczki pod takim właśnie tytułem: The War against the Jews 1933-1945. New York 1976. We wstępie (s. XXI) autorka stawia problem możliwości Holokaustu w kontekście odpowiedzi na trzy pytania: "1. How was it possible for a modern state to carry out the systematic murder of a whole people for no other reason than that they were Jews? 2. How was it possible for a whole people to allow itself to be destroyed? 3. How was it possible for a world to stand by without halting this destruction?". 
był ludobójstwem podobnym do innych czynów z przeszłości, ale też niewykluczonych w przyszłości. Szoa okazała się mordem bezprecedensowym i wyjątkowym w tym znaczeniu, że intencja działania i sam realny jego akt dokonały się najpełniej, a to oznacza, że do nazistowskiej definicji ludobójstwa nie sposób już nic więcej dodać. W tym sensie Holokaust jest eksterminacją kompletną, która może zostać powtórzona, nie tracąc nic ze swej wyjątkowości ${ }^{33}$.

Odwołując się zatem do koncepcji Berela Langa, próbowałem określić wyjątkowość Zagłady w odniesieniu do innych genocydów w wymiarze ahistorycznym, to znaczy bez wikłania się w przyczynowo-skutkowy kontekst dziejów i wskazywania na wpływ poszczególnych faktów historycznych na ogólną kondycję ludzkości. Nie kwestionując znaczenia Holokaustu, ale też nie umniejszając wagi innych ludobójstw, wyznaczenie wyjątkowości zagłady Żydów w kategoriach całkowitego wypełnienia formy jej intencji ${ }^{34}$, a więc realizacji założonego planu, doprowadziło do tego, że nazistowska zbrodnia ludobójstwa dokonana na społeczności żydowskiej w czasie drugiej wojny światowej zajmuje swoje właściwe i niekwestionowane miejsce nie tylko w historii, w dziejach człowieka, ale być może przede wszystkim w określaniu związku między możliwościami a ich realizacją. Taka wizja - w tym przypadku katastroficzna - może i powinna pozostawać przestrogą dla człowieka i ważnym czynnikiem stale już determinującym jego działania.

\section{Bibliografia}

Arendt H.: Co pozostaje? Günter Gaus rozmawia z Hannah Arendt. Przeł. J. Ka€Ążny. „Przegląd Polityczny” 2002, nr 55, s. 52-57.

Arendt H.: Eichmann in Jerusalem. A Report on the Banality of Evil. New York 1963. Arendt H.: Eichmann w Jerozolimie. Rzecz o banalności zła. Przeł. A. Szostriewicz. Kraków 1987.

${ }^{33}$ Warto zaznaczyć, że jest to koncepcja zasadniczo różna od rozumienia wyjątkowości przypisywanej Holokaustowi często przez badaczy, którzy wskazują na jego historyczne znaczenie. Można przywołać jako przykład cytowaną już w tekście książkę autorstwa A. Milchmana i A. Rosenberga Eksperymenty w myśleniu o Holocauście... Publikacja ta w zasadzie jest poświęcona uzasadnieniu tezy o historyczności Holokaustu jako zdarzenia (wydarzenia lub wydarzania, za Heideggerowym Ereignis) „przekształcającego”, zatem zmieniającego dzieje ludzkości (zob. szczególnie rozdział III: Holocaust - kwestia wyjątkowości, s. 85-115). W tym autorzy dostrzegają wyjątkowość. W przedstawionej w artykule wizji unikalności Holokaustu dominuje coś innego. Chodzi raczej o jego charakter, który w formalnym znaczeniu jest dopełnieniem, można powiedzieć: pełną supozycyjnością idei z działaniem.

${ }^{34}$ Odnośnie do samej formy intencji zob. B. LANG: Nazistowskie ludobójstwo..., s. 46-52. 
Bauer Y.: The Place of the Holocaust in Contemporary History. In: The Nazi Holocaust. Historical Articles on the Destruction of European Jews. Ed. M.R. Marrus. Vol. 1: Perspectives on the Holocaust. London 1989, s. 225-248.

Bauman Z.: Modernity and the Holocaust. Ithaca 2000.

Bauman Z.: Nowoczesność i Zagłada. Przeł. T. Kunz. Warszawa 2009.

Dawidowicz L.: The War against the Jews 1933-1945. New York 1976.

Friedländer S.: Czas eksterminacji. Nazistowskie Niemcy i Żydzi 1939-1945. Przeł. S. Kupisz, A.M. NowaK, K. MasŁowski. Warszawa 2010.

Gebert K. (Warszawski D.): Nazywanie nieszczęścia. „Polityka” 2009, nr 45, s. 32-33.

Gilbert M.: The Question of Bombing Auschwitz. In: The Nazi Holocaust. Historical Articles on the Destruction of European Jews. Ed. M.R. Marrus. Vol. 9: The End of the Holocaust. London 1989, s. 249-305.

Hilberg R.: Zagłada Żydów europejskich. T. 1. Przeł. J. GiebuŁtowicz. Warszawa 2014.

Konwencja w sprawie zapobiegania i karania zbrodni ludobójstwa uchwalona przez Zgromadzenie Ogólne Narodów Zjednoczonych dnia 9 grudnia 1948 roku (ratyfikowana zgodnie z ustawa z dnia 18 lipca 1950 r.). „Dziennik Ustaw” 1952, nr 2, poz. 9.

Lang B.: Nazistowskie ludobójstwo. Akt i idea. Przeł. A. Zį̨вińska-Witek. Lublin 2006.

Lang B.: Philosophical Witnessing. The Holocaust as Presence. Waltham 2009.

LEMkin R.: Akte der Barbarei und des Vandalismus als „delicta juris gentium“. „Anwaltsblatt Internationales"1933, 19. Jahrgang, Heft 6.

LEMkin R.: Axis Rule in Occupied Europe: Laws of Occupation, Analysis of Government, Proposals for Redress. Washington 1944.

Lemkin R.: Rządy państw Osi w okupowanej Europie. Prawa okupacyjne, analiza rzadzenia, propozycje zadośćuczynienia. Przeł. A. Bieńczyk-Missala i in. Warszawa 2013.

Longerich P.: Konferencja w Wannsee. Droga do „Ostatecznego rozwiązania”. Przeł. B. NowACKi. Warszawa 2018.

Milchman A., Rosenberg A.: Eksperymenty w myśleniu o Holocauście. Auschwitz, nowoczesność i filozofia. Przeł. L. Krowicki, J. SzAcki. Warszawa 2003.

Miniszewski M.: Architektura zła. Wyjątkowość Holokaustu jako problem filozoficzny. Kęty 2012.

Nuremberg Trial Proceedings. Vol. 19: One Hundred and Eighty-Second Day-One Hundred and Eighty-Ninth Day. Dostępne w Internecie: https://avalon.law.yale.edu/ imt/07-26-46.asp [data dostępu: 11.06.2019].

Rosenfeld A.H.: Kres Holokaustu. Przeł. R. Czekalska, A. Kuczkiewicz-Fraś. Kraków 2013.

Sartre J.-P.: Genocide. "New Left Review” 1968, 1/48, s. 11-26.

TAL U.: On the Study of the Holocaust and Genocide. In: The Nazi Holocaust. Historical Articles on the Destruction of European Jews. Ed. M.R. Marrus. Vol. 9: The End of the Holocaust. London 1989, s. 179-224.

Wyman D.S.: Why Auschwitz Was Never Bombed. In: The Nazi Holocaust. Historical Articles on the Destruction of European Jews. Ed. M.R. MArrus. Vol. 9: The End of the Holocaust. London 1989, s. 306-331. 
JACEK Surzyn - dr hab., prof. w Instytucie Filozofii Akademii Ignatianum w Krakowie. Od lat zajmuje się problematyką żydowską, ze szczególnym uwzględnieniem ideologii syjonistycznej. Autor wielu artykułów wydanych w czasopismach „Midrasz” i „Miasteczko Poznań”. Autor przekładu książki twórcy ruchu syjonistycznego Teodora Herzla pod tytułem Państwo Żydowskie. Próba nowoczesnego rozwiązania kwestii żydowskiej (2006). 